\title{
THE INFLUENCE OF DIFFERENT TYPES OF REST ON FOOTBALL PLAYERS' ABLLTYY TO REPEAT PHOSPHAGEN EXERCISE
}

\author{
Paweł Wolański, ${ }^{A, B, C, D}$ Marek Zatoń, ${ }^{A, E}$ Eugenia Murawska-Ciałowicz, ${ }^{\mathrm{A}, \mathrm{C}} \mathrm{D}$ \\ Department of Physiology and Biochemistry, University School of Physical Education in Wrocław, Poland \\ A Study Design; ${ }^{\mathrm{B}}$ Data Collection; ${ }^{\mathrm{C}}$ Statistical Analysis; ${ }^{\mathrm{D}}$ Manuscript Preparation; ${ }^{\mathrm{E}}$ Funds Collection \\ Address for correspondence: \\ Paweł Wolański, MSc \\ University School of Physical Education in Wrocław, Department of Physiology and Biochemistry \\ J.I. Paderewskiego 35 Street, 51-612 Wrocław, Poland \\ E-mail: pawel.wolanski@onet.pl
}

\begin{abstract}
Ahstract. The aim of the study was to asses the influence of the type of rest on football players' ability to repeat a phosphagen exercise. Twelve football players from the Polish third league were involved in the study and were subjected to a maximum power test on a cycloergometer. Respiratory parameters, lactic acid concentration in capillary blood and acid-base balance parameters were registered before, during and after the test. The test was carried out twice. During the first test the subjects used an active rest break (A) and during the second one they used a passive rest break (B). In part A the quantity of relative work was $87.61 \pm 9.25 \mathrm{~J} / \mathrm{kg}$ and in part $B$ it was $78.5 \pm 6.58 \mathrm{~J} / \mathrm{kg}(p=0.012)$. In test $A$ during exertion and during restitution (4th minute) we registered higher values of the respiratory parameters $\left(\mathrm{Rf}, \mathrm{VE}, \mathrm{VO}_{2}, \mathrm{VO}_{2} / \mathrm{kg}\right.$ ). Our conclusion is that passive rest should be used when the objective is the fastest resynthesis of PCr and ATP. An active rest break should be used when the goal is to remove the accumulated LA as soon as possible.
\end{abstract}

KeV WOrlls: phosphagen power, RAS - repeated sprint ability, football, restitution, acid-base balance

\section{Introduction}

In recent years the evolution of football has made the requirements of the game increase (Vaeyens et al., 2006). Football professionals search for new possibilities of development to improve the quality of the training process and to achieve better results in coaching players. Success can only be achieved by complex training which consist of physiological, psychological, tactical and technical aspects (Bangsbø et al., 2000; Elferink-Gemser et al., 2004; Reilly et al., 2000; Williams, Reilly, 2000). Appropriate physical preparation is very important to gain high and stable physical shape during long and hard seasons (best teams play over 60 matches per year). Modern football makes significant energetic demands on players and their ability to repeat submaximal and maximal effort a lot of times is crucial for accomplishing tactical and technical aims (laia et al., 2009). On average, every 90 seconds a player accelerates with a maximum speed of over $32 \mathrm{~km} / \mathrm{h}$ (Hoff 2005; Michalczyk et al., 2010). Sprint distances covered during sports competitions range from 5 to 30 meters and last for 1 to 4 seconds (Chmura, Zatoń, 2011; 
Michalczyk et al., 2010). They constitute $96 \%$ of all sprints observed during football matches (Mohr et al., 2003). Most of the sprints are preceded by rapid deceleration and rapid and frequent changes of the direction of movement (Miller et al., 2007). Explosive efforts undertaken by players constitute $5 \%$ of the whole game time (Cometti, 2002). They include: dynamic starts, low distance accelerations, changes of the direction of movement, tackles and jumps to head the ball. The ability to undertake these kinds of efforts in the shortest possible intervals is a parameter that distinguishes top class players from amateurs. Only players who can overcome fatigue, have high resources of phosphocreatine $(\mathrm{PCr})$ in the muscles and the ability to restore its resources fast, who have a higher proportion of type-II muscle fibers are able to compete with opponents and participate at the highest levels of football competition (Chmura, Zatoń, 2011).

A player's organism responds differently to a single maximal short-time exercise and differently to its further repetitions. It is important to use an appropriate break before the next maximal exercise. If the time and character of the break is not appropriate, a rapid build-up of fatigue occurs. Overcoming fatigue barriers leads to the development of adaptive changes whose direction and dynamics depend on the type and intensity of the stimulus (Abbiss, Laursen, 2005; Gharbi et al., 2015). Exercise that is continued for a long period of time and accompanied by excessive fatigue, with a break too short for the restoration of energy reserves (creatine phosphate and glycogen) to take place, leads to a faster activation of the glycolytic transition whose byproduct is lactate accumulating in the muscles and the blood (McAinch et al., 2004). This results in prolonged reaction time, a decrease in the speed of decision making and in the speed of locomotion. Not only can the time of the rest break be chosen but it is also possible to determine its character (passive or active). The type of rest break and its duration will affect the whole process of regeneration and an athlete's readiness to do another exercise (Rey et al., 2012). The most suitable type of break should be chosen individually. The same type of break and the same duration may affect players in various ways, which is associated with differences in the level of aerobic capacity, fatigue tolerance, muscle fiber structure and energy resources (Chmura, 2001). Passive rest is not often used in phosphagen training. More often some kind of active rest is used (jog trot, march). Anaerobic efforts are mostly interrupted by active rest breaks which accelerate the restoration of energy compounds (ATP and PCr), and maintain the alertness of the nervous-muscular system (Chmura, 2001). Dupont, Moalla, Guinhouya, Ahmaidi, Berthoin (2004) believe that during maximal shorttime efforts ( $<6$ seconds), which are separated by a short break ( $<30$ seconds), a passive break is more appropriate for the reconstruction of ATP and PCr, but during an active break the removal of the accumulated lactate from the muscles proceeds faster. Phosphagen training should be planned in such a way as to prepare the player for conditions similar to the match load. Depending on the situation on the pitch the player may undertake in a very short period of time (10 to 15 seconds) several different actions based on phosphagen energy pathways, e.g. tackling, jumping, sprinting, or striking the ball into the goal, and repeat them at irregular intervals, and then stand a bit longer on the pitch, jog trot or march. According to Spencer et al. (2004) players who do sprints lasting for up to 6 seconds require rest breaks of up to 30 seconds in order to perform another maximal exercise.

The aim of the study was to assess the influence of the type of rest breaks on football players' ability to repeat phosphagen efforts in order to achieve maximum power and to determine which type of break - passive or active has a more favorable impact on the rate of restitution. The additional objective was to determine whether the degree of acidification of the body is different after passive and active breaks in repeated phosphagen efforts. 


\section{Methods}

A group of 12 third league players was involved in the investigation. The subjects were provided with detailed information about the experiment and they gave their written consent to participate in the study. Table 1 shows selected anthropological parameters of the study group and the practice period.

Tahle 1. Averages and standard deviations of the selected parameters from tests $A$ and $B$ before the tests

\begin{tabular}{cccccccc}
\hline \multirow{2}{*}{ Test } & \multicolumn{7}{c}{ Parameter } \\
\cline { 2 - 8 } & age (years) & body mass $(\mathrm{kg})$ & body height $(\mathrm{cm})$ & BMl & fat tissue $(\%)$ & LBM $(\mathrm{kg})$ & years of experience \\
\hline $\mathrm{A}$ & \multirow{2}{*}{$22.09 \pm 3.77$} & $71.75 \pm 7.98$ & \multirow{2}{*}{$177 \pm 6.24$} & $22.87 \pm 1.43$ & $11.74 \pm 2.63$ & $63.18 \pm 5.62$ & $12.08 \pm 3.63$ \\
$\mathrm{~B}$ & & $72.23 \pm 8.19$ & & $22.98 \pm 1.50$ & $11.99 \pm 3.25$ & $63.37 \pm 5.35$ & \\
\hline
\end{tabular}

The study was conducted in the Laboratory of Testing Efforts at the University School of Physical Education in Wroclaw (Certificate PN-EN ISO 9001: 2001). The study began on 8th October, 2012 and was completed on 30th October, 2012. The research was conducted during the ongoing league games. For this reason the experiment was not conducted sooner than 72 hours after the last match of the investigated players so that they were fully rested. During this period the players were subjected to two independent maximum power tests on a cycloergometer. The research was done in compliance with good ethical standards (Kruk, 2013).

\section{Procedures}

The maximum power test was conduced twice; an active break was used in the first test and a passive break in the second one. The interval between the first and the second tests was $9 \pm 5$ days. The test was performed on a Monark 894 EA ergometer (Monark Exercise $A B$, Sweden). It was preceded by a 5 minute warm-up on a cycloergometer and the test objective was to obtain the maximum power $\left(P_{\max }\right)$ as soon as possible. The test was similar to the Wingate test. External load during the warm-up ranged from 0.5 to $2 \mathrm{~kg}$. The intensity of the warm-up enabled the subject to reach the heart rate of 140 to 160 beats $/ \mathrm{min}$. In both tests each of the players performed 5 repetitions. The test involved obtaining $P_{\max }$ as soon as possible in each successive repetition. The duration of each repetition was $7.56 \pm 1$ seconds. Subsequent repetitions of the test were terminated when the value of the obtained maximum power decreased by $5 \%$. The interval between successive repetitions was 90 seconds in both types of break. The active break consisted in the work of the lower limbs on a cycloergometer without external load, while the passive break consisted in a subject sitting on the cycloergometer and not doing any exercise. The weight, height and body composition of the players were also examined. The value of body weight was used to calculate the individual load for the lower limbs in the exercise test. It equaled $74 \mathrm{~N} / \mathrm{kg}$ of the subject's body mass. The measurement of body composition was performed with FUTREX 6100/XL (Futrex, USA) prior to the effort test. The absolute fat content was examined $(\% \mathrm{~kg})$, BMI and LBM $(\mathrm{kg})$ were calculated. Respiratory parameters were measured with a Quark $b^{2}$ gas analysis system (Cosmed, Milan, Italy). The subjects breathed through a facemask, which using appropriate wiring, was connected with the exhaled breath analyzer. The entire process of the registration of respiratory parameters started 2 minutes before exercise and finished 5 minutes after its completion. It measured oxygen uptake, which was automatically reported in litres per minute and in millimeters per minute per kilogram of body mass $\left(\mathrm{VO}_{2} / \mathrm{kg}\right)$, respiratory rate (Rf), minute ventilation (VE). Lactic 
acid concentration (LA) in the blood was assayed with a Lactate Cuvette Test colorimetric reagent kit (Dr. Lange, Germany). The normal value was $0.6-0.9 \mathrm{mmol} / \mathrm{l}$. LA measurements were performed before the test - at rest, 2 minutes after the second repetition, 2 minutes after the completion of the test. Acid-base balance parameters were determined with a Rapidlab 348 analyzer (Bayer, Germany) at the same time as LA concentrations. The blood $\mathrm{pH}$, partial pressure of oxygen $\left(\mathrm{PO}_{2}\right)$, partial pressure of carbon dioxide $\left(\mathrm{PCO}_{2}\right)$, base buffering deficit $(\mathrm{BE})$, oxygen saturation $\left(\mathrm{O}_{2 \mathrm{SAT}}\right)$ were also measured.

\section{Statistical analysis}

The obtained results of breath-by-breath measurements of respiratory parameters $\left(\mathrm{VO}_{2}, \mathrm{VO}_{2} / \mathrm{kg}, \mathrm{Rf}, \mathrm{VE}\right)$ were recorded at 5 -second intervals, then the results of five repetitions of exercise and restitution were individually averaged out. STATISTICA 10 was used for statistical analysis. Wilcoxon matched -pairs signed-rank test was used to assess differences between tests $A$ and $B$. In the applied statistical test the level of $p<0.05$ was considered statistically significant.

\section{Results}

In the study we observed significant differences in the tested respiratory parameters during five repetitions of maximum intensity efforts and 4 minutes after the completed tests, as well as in the amount of relative and total work. The recorded results showed that the average total work done during test $A$ with an active break was larger compared with test $B$ with a passive break and equaled $6.26 \pm 0.76 \mathrm{~kJ}$. In test $B$ the total average work done by players was $5.66 \pm 0.6 \mathrm{~kJ}(p=0.015)$ (Figure 1). Also, the relative work was higher in test $A(87.61 \pm 9.25 \mathrm{~J} / \mathrm{kg})$. In test $B$ the average relative work equaled $78.5 \pm 6.58 \mathrm{~J} / \mathrm{kg}(p=0.012)$ (Figure 2$)$.

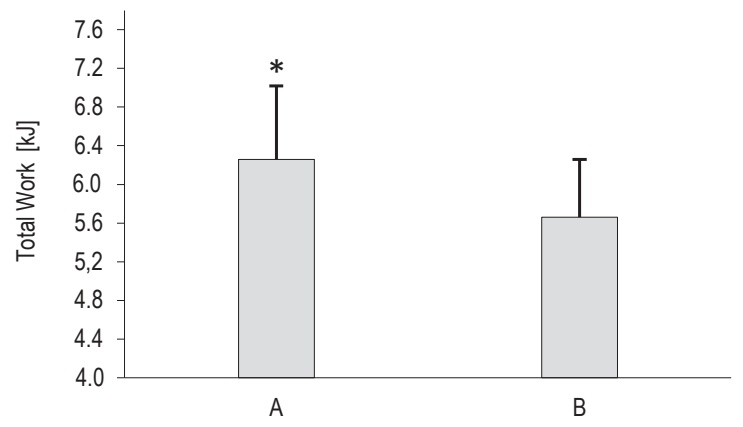

Figure 1. Total work done by participants during tests with active (A) and passive (B) rest breaks. * $p=0.015$

Our study did not show that the application of various types of rest breaks has an impact on maximum power indicators. In test $A$ the players generated the maximum average power which equaled $780.29 \pm 77.43 \mathrm{~W}$. In test $\mathrm{B}$ the average maximum power was $783.51 \pm 72.36 \mathrm{~W}$. The differences were not statistically significant. Analysis of the time needed to obtain and maintain maximum power shows that the type of rest break (passive or active) had no significant effect on these parameters. In test $A$ the average time for the subject to reach maximum power was 
$4.82 \pm 0.56$ seconds. In test $B$ it was $4.92 \pm 0.77$ seconds. In test $A$ the subject was able to maintain maximum power for $2.72 \pm 0.25$ seconds, in test $B$ it was $2.65 \pm 0.29$ seconds.

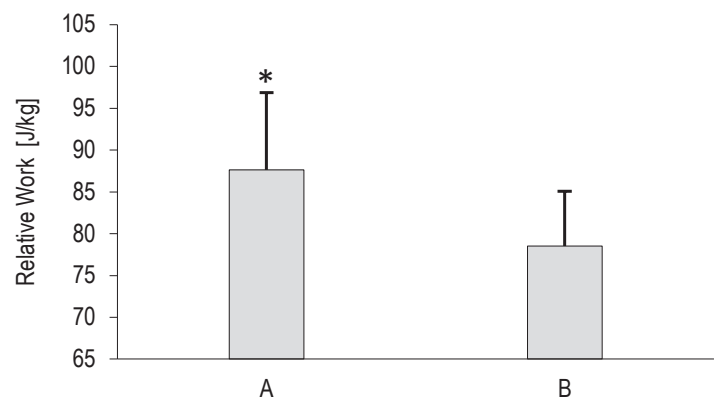

Figure 2. Relative work done by participants during tests with active (A) and passive (B) rest breaks. ${ }^{*} p=0.012$

Table 2. Averages and standard deviations of the respiratory parameters in tests A and B. ${ }^{*}$ - significant differences

\begin{tabular}{|c|c|c|c|c|}
\hline & Respiratory parameters & $A(N=12)$ & $B(N=12)$ & $p$ \\
\hline & baseline values & $16.37 \pm 5.32$ & $15.68 \pm 6.13$ & 0.937 \\
\hline & during rest breaks & $27.84 \pm 6$ & $29.03 \pm 9.98$ & 0.638 \\
\hline $\mathrm{Rf}$ & during exertion & $36.78 \pm 9.17$ & $29.83 \pm 4.69$ & $0.008^{*}$ \\
\hline \multirow[t]{5}{*}{$\mathrm{b} / \mathrm{min}$} & after exertion & $29.26 \pm 4.14$ & $27.77 \pm 4.66$ & 0.084 \\
\hline & 1st minute of restitution & $29.37 \pm 6.85$ & $26.76 \pm 4.13$ & 0.209 \\
\hline & 4th minute of restitution & $33.48 \pm 4.40$ & $24.75 \pm 4.72$ & $0.003^{*}$ \\
\hline & baseline values & $17.54 \pm 7.36$ & $17.19 \pm 7.75$ & 0.583 \\
\hline & during rest breaks & $44.04 \pm 10.13$ & $40.33 \pm 15.57$ & 0.695 \\
\hline VE & during exertion & $80.99 \pm 7.22$ & $64.65 \pm 20.19$ & $0.003^{*}$ \\
\hline \multirow[t]{5}{*}{$1 / \min$} & after exertion & $72.48 \pm 12.62$ & $64.09 \pm 23.5$ & $0.041^{*}$ \\
\hline & 1st minute of restitution & $56.38 \pm 11.27$ & $51.04 \pm 16.56$ & 0.583 \\
\hline & 4th minute of restitution & $47.35 \pm 8.28$ & $26.14 \pm 10.29$ & $0.002^{*}$ \\
\hline & baseline values & $7.30 \pm 2.63$ & $7.42 \pm 2.79$ & 0.937 \\
\hline & during rest breaks & $15.15 \pm 2.19$ & $13.61 \pm 2.07$ & $0.023^{*}$ \\
\hline \multirow{6}{*}{$\begin{array}{l}\mathrm{VO}_{2} / \mathrm{kg} \\
\mathrm{ml} / \mathrm{min} / \mathrm{kg}\end{array}$} & during exertion & $30.15 \pm 3.88$ & $26.53 \pm 4.14$ & $0.004^{*}$ \\
\hline & after exertion & $31.36 \pm 4.75$ & $29.13 \pm 3.71$ & 0.071 \\
\hline & 1st minute of restitution & $20.96 \pm 4.26$ & $20.36 \pm 3.98$ & 0.272 \\
\hline & 4th minute of restitution & $17.52 \pm 2.53$ & $9.31 \pm 2.41$ & $0.002^{*}$ \\
\hline & baseline values & $533.83 \pm 233.16$ & $533.29 \pm 210.51$ & 0.875 \\
\hline & during rest breaks & $1084.2 \pm 176.73$ & $979.19 \pm 161.1$ & $0.034^{*}$ \\
\hline \multirow{6}{*}{$\begin{array}{l}\mathrm{VO}_{2} \\
\mathrm{ml} / \mathrm{min}\end{array}$} & during exertion & $2149.75 \pm 265.17$ & $1892.61 \pm 218.81$ & $0.005^{*}$ \\
\hline & after exertion & $2240.71 \pm 355.12$ & $2090.96 \pm 284.48$ & 0.060 \\
\hline & 1 st minute of restitution & $1497.44 \pm 295.5$ & $1449.95 \pm 210.54$ & 0.308 \\
\hline & 4th minute of restitution & $1254.13 \pm 211.24$ & $668.18 \pm 172.34$ & $0.002^{*}$ \\
\hline & baseline values & $1.1 \pm 0.13$ & $1.09 \pm 0.16$ & 0.937 \\
\hline & during rest breaks & $1.3 \pm 0.17$ & $1.36 \pm 0.15$ & 0.239 \\
\hline \multirow{4}{*}{$R$} & during exertion & $1.16 \pm 0.09$ & $1.2 \pm 0.08$ & 0.117 \\
\hline & after exertion & $1.05 \pm 0.07$ & $1.06 \pm 0.08$ & 0.583 \\
\hline & 1st minute of restitution & $1.18 \pm 0.08$ & $1.19 \pm 0.11$ & 0.875 \\
\hline & 4th minute of restitution & $1.08 \pm 0.11$ & $1.19 \pm 0.1$ & $0.002^{*}$ \\
\hline
\end{tabular}




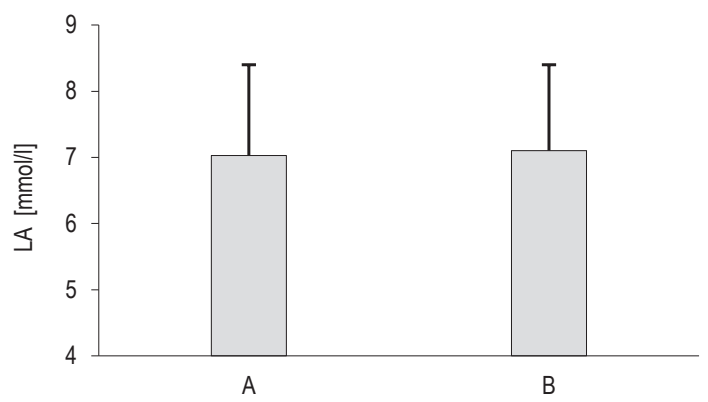

Figulpe 3. LA concentration in the blood, 2 minutes after the second repetition in tests with active (A) and passive (B) rest breaks

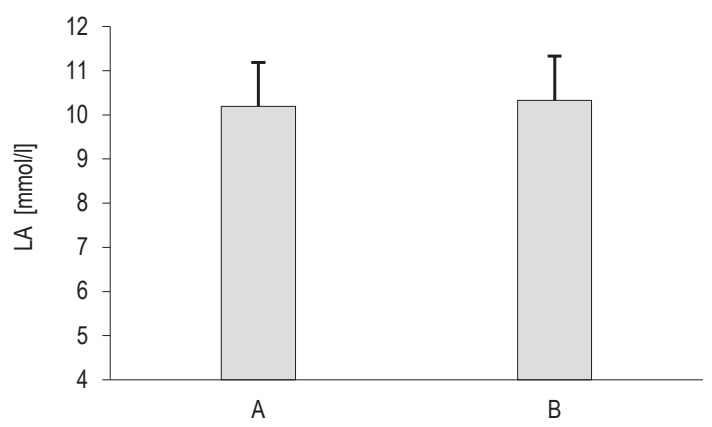

Figure 4. LA concentration in the blood, 2 minutes after the completion of tests with active (A) and passive (B) rest breaks

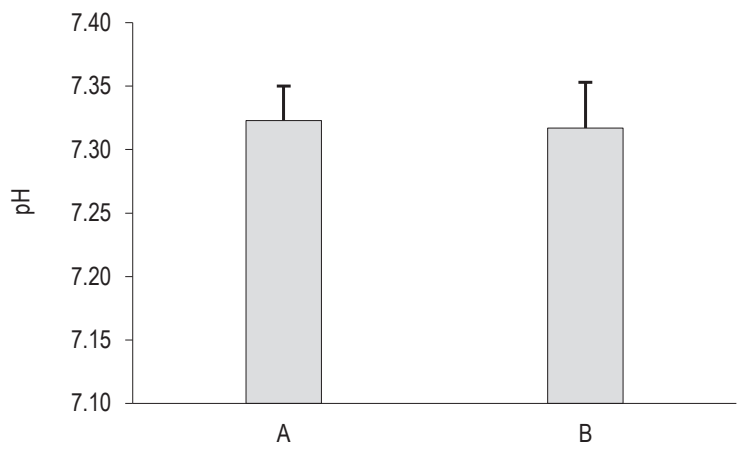

Figure 5. Blood pH values, 2 minutes after the second repetition in tests with active (A) and passive (B) rest breaks 


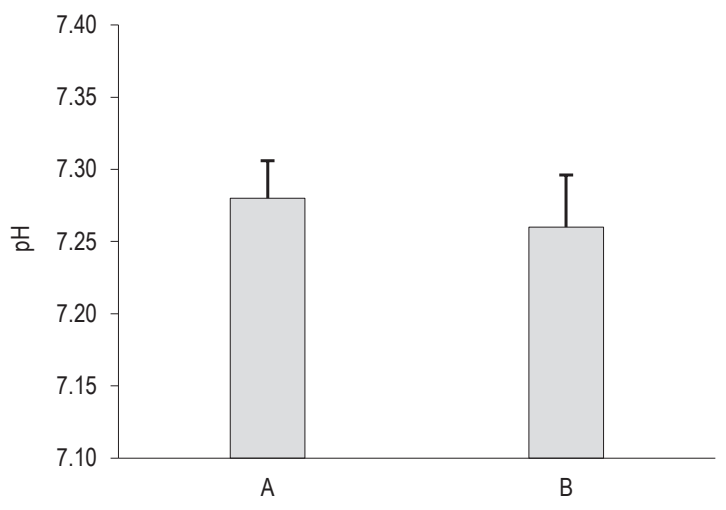

Figulp 6. Blood pH values, 2 minutes after the completion of tests with active (A) and passive (B) rest breaks

We did not register any differences between the selected respiratory parameters at rest, while significant differences were noted in all the parameters during exercise and 4 minutes after its completion. Statistically significant differences were found in VE after completing the exercise. Significantly higher values were recorded during rest breaks in test $A$. It was ascertained that the respiratory parameters were significantly different at corresponding stages in both tests.

Data analysis of acid-base balance and concentration of lactate did not reveal any significant influence of the type of rest break on these parameters. After finishing the tests the concentration of LA in test $A$ was $10.19 \pm 1.67 \mathrm{mmol} / /$ (Figure 4), while in $B$ it was $10.33 \pm 1.57 \mathrm{mmol} / \mathrm{l}$. The $\mathrm{pH}$ of the blood after finishing test A decreased to $7.280 \pm 0.026$, whereas after finishing test $B$ it was $7.260 \pm 0.036$.

\section{Discussion}

According to Maughan, Geeson, Greenhaff (1997) restoration of $90 \%$ of the stock PCr takes about two minutes. McAinch et al. (2004) claim that an active rest break is more beneficial between successive maximal repetitions. Thiriet et al. (1993) state that an active rest break performed with an intensity of $30-40 \% \mathrm{VO}_{2}$ max facilitates utilization of lactic acid which has been accumulated in the muscles as a result of performed maximal efforts. These authors claim that this type of rest break has a beneficial effect on power indicators obtained in subsequent repetitions. In contrast, Dupont et al. (2004) show in their study that a 15 -second active break $\left(40 \% \mathrm{VO}_{2} \max \right)$ applied after subsequent 15 -second efforts $\left(120 \% \mathrm{VO}_{2}\right.$ max) leads to more rapid exhaustion (427 \pm 118 seconds) than when a 15 -second passive break is used. The authors noted that in a test with a passive break the participants performed their work much longer (962 \pm 314 seconds) ( $p=0.001)$. It may be connected with the observed drop in the concentration of oxyhemoglobin in the blood. Furthermore, according to these authors, and Yoshida, Watari, Tagawa (1996) an active break limits re-oxidation of myoglobin and causes slower re-synthesis of phosphocreatine (PCR) in the muscles. McAinch et al. (2004) claim that during an active break the ATP produced in the mitochondria could be partly used during active work between subsequent repetitions. In contrast, during a passive break a greater number of mitochondria could be involved in PCR re-synthesis. The arguments seem to be confirmed by 
Spencer, Bishop, Dawson, Goodman, Duffield (2006). In their research they noticed that after six 4-second runs on a cycloergometer separated by 25 -second intervals with active $\left(32 \% \mathrm{VO}_{2} \max \right)$ and passive rest breaks in two independent tests the reconstruction of phosphocreatine was more effective during a passive break. Baseline $\mathrm{PCr}$ concentration in the muscles before the test was $72.7 \pm 6.6 \mathrm{mmol} / \mathrm{kg}$. In the study by Spencer et al. (2006) after the completion of the test a muscle biopsy was performed in $21 \mathrm{st}$ second of restitution which revealed the reconstruction of phosphocreatine at the level of $52.3 \pm 11.3 \mathrm{mmol} / \mathrm{kg}(71.7 \pm 14.1 \%)$ in the test with a passive break. The test with an active rest break allowed the muscles to rebuild PCr at $39.2 \pm 11.00 \mathrm{mmol} / \mathrm{kg}(54.6 \pm 9.6 \%, p=0.06)$. The concentration of PCr immediately after the test was $23.4 \pm 10.4 \mathrm{mmol} / \mathrm{kg}(32.6 \pm 10.6 \%)$ for the test with an active break and $33.2 \pm 15.3 \mathrm{mmol} / \mathrm{kg}(45.3 \pm 18.6 \%, p=0.06)$ for the test with a passive break. It should also be noted that during the study statistically significant differences in maximum power were noted only in the sixth repetition. It was lower in the test with an active rest break $(14.9 \pm 1.5 \mathrm{~W} / \mathrm{kg})$ than in the test with a passive rest break $(15.3 \pm 1.5 \mathrm{~W} /$ $\mathrm{kg}) \mathrm{p}=0.02$. Dupont et al. (2004) point out that the use of active breaks $\left(40 \% \mathrm{VO}_{2} \mathrm{max}\right)$ for supramaximal exercise $\left(120 \% \mathrm{VO}_{2}\right.$ max) will cause its working time to be twice as short as when a passive break is used. Our research shows that during the test with an active break the participants did a lot more work. It should be noted that in our study the ratio of exercise time to pause time was 1 to $12 \pm 1$. Implementation of more work during the first test may be related to an increased volume of blood flowing through the muscles, providing them with significant amounts of oxygen, which can improve lactate transport from the muscles by MCT transporters (Brookes, 1986; Harmer et al., 2000; McKenna et al., 1997). Chmura, Zatoń (2011) suggest that repetition of 90-second efforts might lead to energy from glycolytic processes being used. This is also confirmed by our study, in which LA concentration after the second repetition (Figure 3) was $>7 \mathrm{mmol} / \mathrm{l}$. During 6-second maximal effort the participation of phosphocreatine in ATP resynthesis is approx. 50\% (Gaitanos et al., 1993). However, if the effort lasts for 30 seconds, PCr reserves are depleted by approximately $60-80 \%$ relative to the resting value (Gaitanos et al., 1993; Medbø et al., 1999). In their study Bogdanis, Nevill, Lakomy, Boobis (1998) observed PCr resynthesis at $86 \%$ after 10 seconds of maximal effort on a cycloergometer, and after 20 seconds it reached $76 \%$. These values were observed in the 2 nd minute of restitution after a single effort. Therefore, it can be concluded that in our own study in which subsequent efforts lasted from 7 to 9 seconds anaerobic processes were more engaged in ATP re-synthesis. The obtained results of maximum power in tests $A$ and $B$ suggest that the type of rest break did not affect the rate of PCr re-synthesis, but because of the higher level of work in test A it can be assumed that ATP re-synthesis is less difficult than in test $B$. ATP resynthesis is more effective during an active rest break after short intense exercise as compared with a passive break (in accordance with Sechenov's principle). Thevenet, Tardieu-Berger, Borthoin, Prioux (2006) claim that both passive and active rest breaks between efforts improve the body's oxygen systems. The type of break should be chosen consciously and properly and should be determined by changes which we expect to achieve in the body. An active rest break will cause faster neutralization of LA while a passive rest break will cause faster resynthesis of $\mathrm{PCr}$ and faster adaptation of the muscles to work in conditions of disturbed acid-base balance. After two independent tests on a cycloergometer with active and passive breaks, McAinch et al. (2004) documented that a passive rest break has a better influence on $\mathrm{PCr}$ re-synthesis and ATP restoration. In the $15^{\text {th }}$ second of restoration they even observed supercompensation of ATP and PCr in relation to the baseline. ATP concentration recorded prior to the test was $26.1 \pm 1.6 \mathrm{mmol} / \mathrm{kg}$, and after the test, $26.4 \pm 1.8 \mathrm{mmol} / \mathrm{kg}$. In contrast, $\mathrm{PCr}$ concentration prior to the test was $79.4 \pm 2 \mathrm{mmol} / \mathrm{kg}$ and after the test it rose to a value of $87.6 \pm 2.9 \mathrm{mmol} / \mathrm{kg}(p<0.05)$. Higher values 
of $\mathrm{VO}_{2} / \mathrm{kg}$ observed in our study testify to the body's higher ability to perform more work, which is confirmed by Krustrup, Bangsbø (2001), Weston, Brewer (2002), Wisløff, Helgerud, Hoff (1998). Our research has shown that higher $\mathrm{Rf}, \mathrm{VE}, \mathrm{VO}_{2} / \mathrm{kg} \mathrm{VO}_{2}$ recorded during efforts do not affect the maximum power obtained in tests $\mathrm{A}$ and $\mathrm{B}$. Tomlin and Wenger (2001) are of the opinion that a high level of aerobic capacity increases anaerobic performance during short-time intense exercise. The values of $\mathrm{Rf}, \mathrm{VE}, \mathrm{VO}_{2} / \mathrm{kg}, \mathrm{VO}_{2}, \mathrm{R}$ measured 60 seconds after the completion of the tests showed no statistically significant differences between tests $A$ and $B$. In contrast, higher values of these parameters were recorded in the group performing the test with an active rest break. The values of some of these parameters from test A exceeded even twice the values of the corresponding parameters in test B. Taking the body's ability to return after load to resting values as a determinant of the effectiveness of restitution, we should conclude that passive rest is more effective. While analyzing the changes in other parameters, such as the concentration of lactate and the $\mathrm{pH}$, it cannot be unequivocally concluded that a passive rest break is more advantageous.

\section{Practical Applications}

1. The type of rest breaks must be chosen after considering the purpose and the changes that we intend to achieve in players' bodies by introducing specialized training which is responsible for shaping and improving the capacity of selected physiological abilities.

2. In phosphagen training not only the type but also the time of restitution must be selected individually, taking into account fitness levels of competitors and the efficiency of their particular metabolic pathways.

3. A passive rest break should be used when the objective is the fastest resynthesis of PCr and ATP and improvement in the muscles' adaptation to work in disturbed acid-base balance.

4. An active rest break should be used when the goal is to remove LA accumulated in the muscles as soon as possible during subsequent maximal repetitions in anaerobic training. The use of an active rest break is preferred to prepare a player for doing subsequent maximal repetitions in the shortest possible time intervals as is the case in real game conditions. The intensity of work during an active rest break should be $30-40 \% \mathrm{VO}_{2} \max$.

5. Time of both active and passive rest breaks should be considered individually for each player. It is possible to apply the principle of the higher the $\mathrm{VO}_{2}$ max level and the speed abilities of a player are, the shorter the rest break between subsequent repetitions should be.

\section{References}

Abbiss, C.R., Laursen, P.B. (2005). Models to explain fatigue during prolonged endurance cycling. Sports Medicine, 35 (10), 865-898.

Bangsbø, J., Krustrup, P., Gonzalez-Alonso, J., Boushel, R., Saltin, B. (2000). Muscle oxygen kinetics at onset of intense dynamic exercise in humans. American Journal of Physiology. Regulatory Integrative and Comparative Physiology, 279 (3), 899-906.

Bogdanis, G.C., Nevill, M.E., Lakomy, H.K., Boobis, L.H. (1998). Power output and muscle metabolism during and following recovery from 10 and 20 s of maximal sprint exercise in humans. Acta Physiologica Scandinavica, 163 (3), 261-272.

Brookes, G.A. (1986). The lactate shuttle during exercise and recovery. Medicine\& Science in Sports \& Exercise, 18, 360-368.

Chmura, J. (2001). Szybkość w piłce nożnej, Katowice: Wydawnictwo AWF.

Chmura, P., Zatoń, M. (2011). Zmiany maksymalnej mocy fosfagenowej i wybranych cech fizjologicznych podczas powtarzanych wysiłków u młodych piłkarzy nożnych. Antropomotoryka, 54, 51-57.

Cometti, G. (2002) La preparation physique en football, Paris: Chiron. 
Dupont, G., Moalla, W., Guinhouya, C., Ahmaidi, S., Berthoin, S. (2004). Passive versus active recovery duting high-intensity intermittent exercises. Medicine\& Science in Sports \& Exercise, 36, 302-308.

Elferink-Gemser, M.T., Visscher, C., Lemmink, K.A., Mulder, T.W. (2004). Relation between multidimensional performance characteristics and level of performance in talented youth field hockey players. Journal of Sports Sciences, 22, 1053-1063.

Gaitanos, G.C., Williams, C., Boobis, L.H., Brooks, S. (1993). Human muscle metabolism during intermittent maximal exercise. Journal of Applied Physiology, 75 (2), 712-719.

Gharbi, Z., Dardouri, W., Haj-Sassi, R., Chamari, K., Souissi, N. (2015). Aerobic and anaerobic determinants or repeated sprint ability in team sports athletes. Biology of Sport, 32 (3), 207-212. DOI: 10.5604/20831862.1150302.

Harmer, A.R., McKenna, M.J., Sutton, J.R., Snow, R.J., Ruell, P.A., Booth, J., (...), Eager, D.M. (2000). Skeletal muscle metabolic and ionic adaptations during intense exercise following sprint training in humans. Journal of Applied Physiology, 89 (5), $1793-1803$.

Hoff, J. (2005). Training and testing physical capacities for elite soccer players. Journal of Sports Sciences, 23, 573-582.

laia, F.M., Rampinini, E., Bangs $\emptyset$, J. (2009). High-intensity training in football. International Journal of Sports Physiology and Performance, 4 (3), 291-306.

Kruk, J. (2013). Good scientific practice and ethical principles in scientific research and higher education. Central European Journal of Sport Sciences and Medicine, 1 (1), 25-29.

Krustrup, P., Bangsbø, J. Physiological demands of top-class soccer refereeing in relation to physical capacity: effect of intense intermittent exercise training. Journal of Sports Sciences, 19, 881-891.

Maughan, R., Geeson, M., Greenhaff, P.L. (1997). Biochemistry of Exercise \& Training. Oxford: University Press.

McAinch, A.J., Febbraio, M.A., Parkin, J.M., Zhao, S., Tangalakis, K., Stojanovska, L., Carey, M.F. (2004). Effect of active versus passive recovery on metabolism and performance during subsequent exercise. International Journal of Sport Nutrition and Exercise Metabolism, 14, 185-196.

McKenna, M.J., Heigenhauser, G.J., McKelvie, R.S., Obminski, G., MacDougall, J.D., Jones, N.L. (1997). Enhanced pulmonary and active skeletal muscle gas exchange during intense exercise after sprint training in men. Journal of Physiology, 501, 703-716.

Medbø, J.I., Gramvik, P., Jebens, E. (1999). Aerobic and anaerobic energy release during 10 and 30 s bicycle sprints. Acta Kinesiologiae Universitetis Tartuensis, 4, 122-146.

Michalczyk, M., Kłapcińska, B., Poprzęcki, S., Jagosz, S., Sadowska-Krępa, E., Kimas, E., (...), Chmura, J. (2010). Ocena wydolności tlenowej oraz szybkości sprinterskich zawodników I i IV ligi piłkarskiej. Wychowanie Fizyczne i Sport, 54, 13-19.

Miller, T.A., Thierry-Aguilera, R., Congleton, J.J., Amendola, A.A., Clark, M.J., Crouse, S.F., (...), Jenkins,O.C. (2007). Seasonal changes in $\mathrm{VO}_{2}$ max among Division $1 \mathrm{~A}$ collegiate women soccer players. Journal of Strength and Conditioning Research, 21, 48-51.

Mohr, M., Krustrup, P., Bangsbø, J. (2003). Match performance of high-standard soccer players with special reference tcoo development of fatigue. Journal of Sports Sciences, 21, 519-528.

Reilly, T., Williams, A.M., Nevill, A., Franks, A. (2000). A multidisciplinary approach to talent identification in soccer. Journal of Sports Sciences, 18, 695-702.

Rey, E., Lago-Penas, C., Casais, L., Lago-Ballesteros, J. (2012). The effect of immediate post-training active and passive recovery interventions on anaerobic performance and lower limb flexibility in professional soccer players. Journal of Human Kinetics, 31 , 121-129.

Spencer, M., Bishop, D., Dawson, B., Goodman, C., Duffield, R. (2006) Metabolism and performance in repeated cycle sprints: active versus passive recovery. Medicine \& Scinces in Sports \& Exercise, 38 (8), 1492-1499.

Spencer, M., Lawrence, S., Rechichi, C., Bishop, D., Dawson, B., Goodman, C. (2004). Time-motion analysis of elite field hockey, with special reference to repeated-sprint activity. Journal of Sports Sciences, 22 (9), 843-850.

Thevenet, D., Tardieu-Berger, M., Berthoin, S., Prioux, J. (2006). Influence of recovery mode (passive vs. active) on time spent at maximal oxygen uptake during an intermittent session in young and endurance-trained athletes. European Journal of Applied Physiology, 99 (2), 133-142.

Thiriet, P., Gozal, D., Wouassi D., Oumarou, T., Gelas H., Lacour, J.R. (1993) The effect of various recovery modalities on subsequent performance, in consecutive supramaximal exercise. Journal of Sports Medicine and Physical Fitness, 33, 118-129.

Tomlin, D., Wenger, H.A. (2001). The relationship between aerobic fitness and recovery from high intensity intermittent exercise. Sports Medicine, 31, 1-11. 
Vaeyens, R., Malina, R.M., Janssens, M., Van Renterghem, B., Bourgois, J., Vrijens, J., Philippaerts, R.M. (2006). A multidisciplinary selection model for youth soccer: the Ghent Youth Soccer Project. British Journal of Sports Medicine, 40 (11), 928-934.

Weston, M., Brewer, J. (2002). A study of the physiological demands of soccer refereeing. J Sport Sci., 20: 59-60.

Williams, A.M., Reilly, T. (2000). Talent identification and development in soccer. Journal of Sports Sciences, 18, 657-667.

Wisløff, U., Helgerud, J., Hoff, J. (1998). Strength and endurance of elite soccer players. Medicine \& Sciences in Sports \& Exercise, 30 (3), 462-467.

Yoshida, T., Watari, H., Tagawa, K. (1996). Effects of active and passive recoveries on splitting of the inorganic phosphate peak determined by 31P-nuclear magnetic resonance spectroscopy. NMR Biomedicine, 9 (1), 13-19.

Cite this article aS: Wolański, P., Zatoń, M., Murawska-Ciałowicz, E. (2016). The Influence of Different Types of Rest on Football Players' Ability to Repeat Phosphagen Exercise. Central European Journal of Sport Sciences and Medicine, 13 (1), 89-99. DOI: 10.18276/cej.2016.1-09. 
